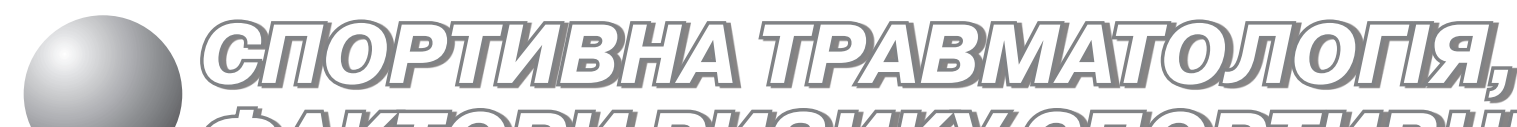

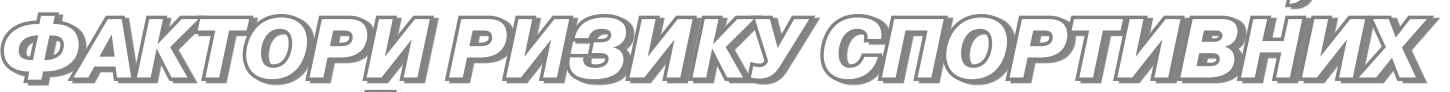

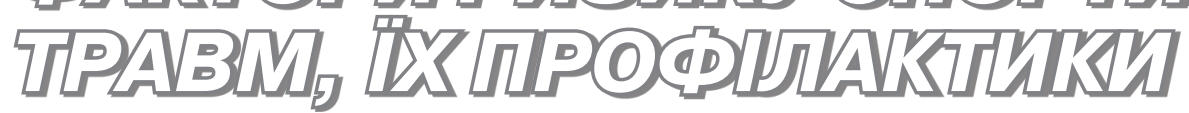

DOI: https://doi.org/10.32652/spmed.2021.1.43-47

\section{Фактори ризику розвитку ускладнень після оперативного лікування переломів кісток надп'ятково-гомілкового суглоба}

\author{
УДК 616.718.6:616-089.168 \\ О. К. Ніканоров, Т. С. Борсукевич
}

Національний університет фізичного виховання і спорту України, Київ, Україна

Резюме. Відомо, що серед усіх ушкоджень нижніх кінцівок переломи надп'ятково-гомілкового суглоба займають досить значне місце. Мета. Визначити та проаналізувати фактори ризику розвитку ускладнень після хірургічного втручання при переломах кісток гомілковонадп'яткового суглоба. Методи. Аналіз та узагальнення спеціальної науково-методичної літератури вітчизняних і зарубіжних авторів та даних мережі Інтернет. Результати. У ході вивчення та аналізу праць вітчизняних та зарубіжних дослідників було встановлено, що помилки при лікуванні даної патології можуть бути на всіх етапах, починаючи від оперативного втручання і закінчуючи неправильною фізичною терапією, через що і виникають ускладнення. Найбільш поширеною серед ранніх ускладнень є хірургічна інфекція, яка може виникнути через недбалість лікарів або самого пацієнта, серед пізніх ускладнень - контрактура, порушення функції суглоба тощо. Акцентується увага на проблемах пацієнтів, які найбільше схильні до отримання післяопераційних ускладнень, і на тому, як з цим боротися в подальшому. 3'ясовано, що ключове місце в успішному лікуванні пацієнтів з переломами кісток надп'ятковогомілкового суглоба займає фізична терапія. Сучасні підходи до фізичної терапії зводяться до максимально раннього її початку (безпосередньо після травми) і закінчення після повного відновлення функції кінцівки. У разі дотримання цих умов пацієнт може досить швидко почати звичайне для нього побутове і трудове життя. Встановлено, що відсутність повноцінного проведення комплексної програми фізичної терапії після переломів кісток надп'ятково-гомілкового суглоба є потужним фактором ризику розвитку ускладнень.

Ключові слова: фактори ризику, ускладнення, остеосинтез, гомілково-надп'ятковий суглоб, фізична терапія.

Risk factors for complications after surgical treatment of fractures of the articulatio talocruralis

\section{O. K. Nikanorov, T. S. Borsukevych}

National University of Physical Education and Sport of Ukraine, Kyiv, Ukraine

Abstract. It is known that among all injuries of the lower extremities, fractures of the articulatio talocruralis are most common. Objective. Identify and analyze risk factors for complications after surgery for articulatio talocruralis fractures. Methods. Analysis and generalization of special scientific and methodical literature of domestic and foreign authors and data of the Internet. Results. In the course of studying and analyzing the works of national and foreign researchers, it was found that 
errors in the treatment of this pathology can occur at all stages, from surgery to improper physical therapy, which causes complications. The most common among the early complications is a surgical infection, which can occur due to negligence of doctors or the patient, whereas among the later contracture, joint dysfunction, etc. Emphasis is placed on the problems of patients who are most prone to postoperative complications, and how to deal with it in the future. Physical therapy has been shown to play a key role in the successful treatment of patients with fractures of articulatio talocruralis joint. Modern approaches to physical therapy are reduced to its the earliest beginning (immediately after injury) and completion after full recovery of extremity function. If these conditions are met, the patient can quickly return to his usual domestic and working life. It has been established that the lack of a comprehensive program of physical therapy after fractures of the articulatio talocruralis joint is a powerful risk factor for complications.

Keywords: risk factors, complications, osteosynthesis, articulatio talocruralis joint, physical therapy.

Постановка проблеми. Відомо, що серед травм нижніх кінцівок переломи кісток надп'ятково-гомілкового суглоба зустрічаються досить часто - 40-60 \% [1]. Частота даної патології становить до 184 переломів на 100000 осіб на рік, з них приблизно 20-30 \% - у літніх людей $[1,5]$. Визнано, що оперативна фріксація нестабільних переломів кісток цього суглоба дає передбачувано хороші результати в загальній популяції [15]. Однак у сучасній науковій літературі $[3,8,12] \epsilon$ повідомлення про менш прийнятні результати, наприклад, у геріатричній віковій популяції 65 років і старше. Погана якість кісткової тканини представляє технічні труднощі, оскільки існує значний ризик некрозу країв рани з відстроченим загоєнням ран, а нездатність пацієнтів рано переносити вагу тіла на ушкоджену кінцівку призводить до тривалого перебування в стаціонарі та важких соціально-економічних проблем [14].

Хірургічне лікування переломів кісток надп'ятково-гомілкового суглоба може супроводжуватися кількома ускладненнями. Загальна частота ускладнень після відкритої редукції і внутрішньої фріксації значно варіює в спеціальній літературі і коливається в межах від 1-40\% [5].

У дослідженні [3] відзначено, що складні переломи в ділянці надп'ятково-гомілкового суглоба належать до тяжких внутрішньосуглобових ушкоджень кісток кінцівок. До особливостей даної категорії переломів відносять: розвиток ускладнень у вигляді деформуючого артрозу і стійких контрактур надп'ятково-гомілкового суглоба та суглобів стопи, комбінованої посттравматичної плоскостопості, неправильного зрощення перелому, підвивиху стопи, посттравматичної дистрофрії стопи, фрормування несправжнього суглоба, аваскулярних некрозів таранної кістки при її переломах, що вимагають проведення довготривалого періоду фрізичної терапії і нерідко повторних реконструктивно-відновлювальних операцій $[6,13]$.

У зв'язку з цим зростає необхідність виявлення найбільш поширених фракторів ризику, які ведуть до ускладнень після оперативного ліку- вання переломів кісток надп'ятково-гомілкового суглоба.

Роботу виконано згідно з планом НДР кафедри фрізичної терапії та ерготерапії НУФВСУ на 2016-2020 рр. за темою 4.2 «Організаційні та теоретико-методичні основи фрізичної реабілітації осіб різних нозологічних, професійних та вікових груп» (номер держреєстрації 0116U001609).

Мета дослідження - визначити фрактори ризику, що спричиняють розвиток ускладнень після хірургічного втручання при переломах кісток надп'ятково-гомілкового суглоба та методи їх запобігання.

Методи дослідження: аналіз і узагальнення спеціальної науково-методичної літератури вітчизняних та зарубіжних авторів, даних мережі Інтернет.

Результати дослідження та їх обговорення. Переломи кісток надп'ятково-гомілкового суглоба в структурі травм опорно-рухового апарату займають одне з перших місць як за частотою, так і за значущістю їх анатомо-фрункціональних наслідків [1]. У 70-80 \% випадків дана травма зустрічається в осіб працездатного віку, з них у $60 \%$ розвивається артроз, а інвалідизація сягає 8,8-46\% [6].

Основним принципом відновлення пацієнтів 3 переломами кісток надп'ятково-гомілкового суглоба після оперативного втручання вважають доцільно проведену комплексну програму фрізичної терапії. Від її повноти залежить успішність відновлення усіх втрачених функцій стопи і гомілки. Тривалість фрізичної терапії визначається тяжкістю травми. Головним завданням $€$ своєчасне звернення за допомогою до фрізичного терапевта.

Проте відновлення після травми має ряд труднощів, які пов'язані з характером перелому, функціональною значущістю суглоба і несприятливими біомеханічними умовами, що діють на суглобову поверхню після травми [10]. Крім того, надп'ятково-гомілковий суглоб, на відміну від інших суглобів, піддається найбільшому на- 
вантаженню на квадратний сантиметр суглобової поверхні [3].

Незважаючи на прогрес у сорері фрізичної терапії для відновлення даної категорії хворих, все ще існують ускладнення, які заважають пацієнтам повернутися до повсякденного життя з нормальною функцією суглоба.

Досить часто ускладнення виникають саме через халатність пацієнтів у ставленні до власного здоров'я, мають умовно суб'єктивний характер і пов'язані з недотриманням встановленого режиму, а саме: несвоєчасне звернення за медичною допомогою; випадкові падіння на оперовану кінцівку; дуже ранні навантаження кінцівки, які можуть призвести до вторинних зміщень уламків, переломів фріксаторів, що вимагають повторних коригуючих втручань; невиправдано пізні навантаження, які, зазвичай, ведуть до розвитку стійких контрактур суглобів і так званого навантажувального остеопорозу, що вимагають проведення тривалого відновлювального лікування; ігнорування проведення повноцінного реабілітаційного лікування з боку пацієнтів, що призводить до значних функціональних розладів, нерідко визначають стійку втрату працездатності тощо [2]. До того ж порушення нормального розподілу ваги тіла сприяє розвитку багатьох патологій опорнорухового апарату - від артритів і артрозів суглобів здорової нижньої кінцівки до гриж міжхребцевих дисків поперекового відділу хребта [4].

Ускладнення можуть виникати під час операції, в ранньому або пізньому післяопераційному періодах [3].

У дослідженнях $[6,11]$ було виявлено, що з 501 перелома кісток надп'ятково-гомілкового суглоба частота ранніх ускладнень після хірургічного лікування становила 5 \%. Проблема переважно була пов'язана з післяопераційною раною у вигляді глибокої інфрекції, яка може мати руйнівні наслідки.

Більш детально зосередимося на пізніх ускладненнях, серед яких розглянемо контрактуру надп'ятково-гомілкового суглоба та посттравматичний остеоартрит.

Втрата руху в надп'ятково-гомілковому суглобі $є$ частим ускладненням, яке можна мінімізувати за допомогою ранніх вправ, спрямованих на розвиток діапазону рухів після досягнення стабільної фіксації [7].

Проведене дослідження [11], в якому 30 пацієнтів було рандомізовано на післяопераційну іммобілізацію в гіпсовій пов'язці протягом 6 тиж. і ранню мобілізацію (через 1-2 тиж. після операції) в надп'ятково-гомілковому суглобі, показало, що пацієнти, які почали ранні рухи, повністю по- збулися болю, мали нормальну ходу і не мали рентгенологічних ознак артрозу.

Основна мета хірургічного лікування переломів кісток надп'ятково-гомілкового суглоба полягає у тому, щоб відновити анатомічну конгруентність [1]. Зміна конгруентності суглоба спричиняє хронічний біль, фрункціональні порушення, погіршення стану суглобового хряща i, нарешті, посттравматичний остеоартрит. Більшість пацієнтів з неправильно зрощеними кістками скаржаться на біль, набряк або тугорухливість у суглобі, а також на труднощі під час ходьби або фрізичної активності [1]. Відновлення анатомії та вирівнювання суглобів при переломах кісток надп'ятково-гомілкового суглоба $€$ фракторами, які можуть запобігти розвитку або прогресуванню остеоартриту [12].

Посттравматичний артрит значно частіше зустрічається серед жінок середнього віку. Найбільш вирішальними фракторами, які впливають на клінічні результати, $є$ тип перелому, стать пацієнта та несвоєчасно проведена програма фрізичної терапії [8].

Пацієнти, які мають підвищений ризик отримання післяопераційних ускладнень, - це ті, які хворіють на цукровий діабет, страждають на ожиріння, вживають алкоголь та тютюн.

Дослідження [11] показали, що пацієнти з діабетом мають підвищений рівень ризику смертності, більше післяопераційних ускладнень, більш тривале перебування у стаціонарі і підвищені витрати порівняно з пацієнтами, які не мають цієї недуги. Ризик отримання інфекції в діабетичній популяції в чотири рази вищий, ніж у недіабетичній [4].

Було виявлено [5], що з 19 пацієнтів з діабетом, яких лікували хірургічним шляхом, у шести розвинулися серйозні ускладнення, включаючи один випадок неправильного зрощення, один випадок некрозу краю рани, який вимагав клаптя, i два випадки глибокого сепсису.

Костіган зі співавт. [6] розглянули 21 пацієнта з цукровим діабетом та ізольованими переломами кісток надп'ятково-гомілкового суглоба, яких лікували оперативно; частота ускладнень становила 43 \%. Ускладнення включали сім інфекцій (п'ять глибоких, дві поверхневі) і три втрати фріксації. Ускладнення були важкими і вимагали семи додаткових процедур, включаючи дві ампутації нижче коліна [9].

У хворих на цукровий діабет має бути суворий післяопераційний контроль рівня глюкози, необхідний для поліпшення обмінних процесів і зменшення імовірних ускладнень [9].

3 огляду на високу поширеність діабету II типу у пацієнтів з ожирінням слід звернути особливу 
увагу на ризики і переваги хірургічного втручання в цій популяції пацієнтів, оскільки існує тісний зв'язок між ожирінням і втратою редукції після оперативного лікування синдезмотичних ушкоджень [3].

Існує прямий зв'язок між вживанням алкоголю і травмами. Алкоголь значною мірою бере участь в епідеміології переломів кісток надп'ятковогомілкового суглоба, а також ускладнює його лікування [12]. Етанол пригнічує фрункцію остеобластів, хронічне його споживання викликає системну втрату кісткової маси, збільшує ризик переломів і ставить під загрозу загоєння ушкодженої кістки [6, 11]. У дослідженні [6] виявлено післяопераційну захворюваність після остеосинтезу переломів кісток надп'ятково-гомілкового суглоба у 90 пацієнтів, які зловживають алкоголем, порівняно з 90 контрольними. В осіб, що зловживають алкоголем, після операції з'явилися більш ранні ускладнення, особливо інфекції.

Куріння також $є$ одним із фракторів ризику поганого загоєння переломів. Було показано, що воно у п'ять разів збільшує ризик розвитку післяопераційної інфекції [12]. Результати досліджень [8] підтверджують ці висновки, оскільки вживання тютюну було найсильнішим предиктором глибокої інфекції навіть після врахування усіх інших факторів. Поточне дослідження також показало, що більшість пацієнтів, які потребують реконструкції інфрікованого надп'ятково-гомілкового суглоба, були курцями. Крім того, куріння було одним $з$ найбільш важливих фракторів, що перешкоджають лікуванню після інфекції перелому кісток даного суглоба [11].

Однак кількість післяопераційних ускладнень можна зменшити за допомогою простих методів: кожному курцеві і тому, хто зловживає алкоголем, які потребують оперативного лікування кісток надп'ятково-гомілкового суглоба, слід кинути палити і пити; рівень глюкози в крові слід оцінювати й оптимізувати у всіх пацієнтів, оскільки його підвищення може спричинити виникнення післяопераційної інфекції навіть у пацієнтів, які не мали раніше цукрового діабету; операція повинна бути відкладена у пацієнтів з порушеною оболонкою м'яких тканин, за умови що гомілково-надп'ятковий суглоб залишається конгруентним [12].

У післяопераційному періоді не слід маніпулювати хірургічними розрізами протягом перших 48 год. Гіпс слід накладати всім пацієнтам, які вже перебувають в операційній, оскільки він за- хищає рану від забруднення і запобігає післяопераційному набряку [8].

Пацієнтам, які несвоєчасно звернулися до спеціалістів або взагалі відмовилися від фрізичної терапії з надією на те, що все само собою заживе, в результаті чого отримали пізні ускладнення (контрактура суглоба, хронічний біль, порушення функції надп'ятково-гомілкового суглоба від легкої скутості до вираженої кульгавості тощо), потрібно серйозніше ставитися до власного здоров'я, обов'язково звернутися до фрізичного терапевта та під контролем спеціаліста пройти курс відновлення, аби запобігти небажаним наслідкам.

Необхідно пам'ятати про те, що саме мультидисциплінарний всебічний підхід до лікування дозволяє скоротити терміни терапії і раніше повернутися до звичного ритму існування. Поєднання медикаментозного лікування, фрізіотерапії, спеціальної лікувальної фрізкультури і масажу знімуть запальні явища, покращать кровообіг, прискорять розсмоктування набряку, збільшать м'язову силу, прискорять відновлення тканин, зміцнять суглоб та допоможуть уникнути можливих ускладнень.

За правильного відновлення переломів кісток надп'ятково-гомілкового суглоба після хірургічного втручання ускладнення зустрічаються нечасто, за умов якщо пацієнт точно дотримується отриманих від лікарів інструкцій, а фрізичним терапевтом правильно побудована програма фрізичної терапії.

Висновки. Описані вище ускладнення, які з'являються після допущених помилок, подовжують терміни лікування пацієнтів і погіршують анатомічні та фрункціональні його результати (близько $17 \%$ випадків), нерідко будучи причиною інвалідності (близько 8 \% пацієнтів).

Правильно поставлений діагноз, дотримання здорового способу життя та адекватно проведена комплексна фрізична терапія кінцівки дозволяють, у переважній більшості випадків, отримати хороші результати.

Перспективи подальших досліджень полягають у більш детальному вивченні фракторів, які можуть спричиняти розвиток ускладнень після оперативного лікування переломів кісток надп'ятково-гомілкового суглоба. Також необхідно показати важливість дотримання програм фрізичної терапії у зазначені терміни для повного відновлення суглоба. 


\section{Література}

1. Хорошков СН, Чемянов ГИ, Доронин НГ, Костяков АЮ. Оперативное лечение пациентов С неблагоприятными последствиями в области голеностопного сустава [Surgical treatment of patients with adverse consequences in the ankle joint]. Тезисы докладов I научно-практической консреренции «Актуальные вопросы ортопедии. Достижения. Перспективы»; Москва. 2012; 130-1.

2. Anderson SA, Li X, Franklin P, Wixted JJ. Ankle fractures in the elderly: initial and long-term outcomes. Foot Ankle Int [Internet]. 2008; 29(12):1184-8. Available from: $h$ ttp://dx.doi.org/10.3113/FAl.2008.1184

3. Bachoura A, Guitton TG, Smith RM, Vrahas MS, Zurakowski D, Ring D. Infirmity and injury complexity are risk factors for surgical-site infection after operative fracture care. Clin Orthop Relat Res [Internet]. 2011; 469:2621-30. Available from: $h$ ttp://dx.doi.org/10.1007/s11999-010-1737-2

4. Bariteau JT, Hsu RY, Mor V, Lee Y, DiGiovanni CW, Hayda R. Operative versus nonoperative treatment of geriatric ankle fractures: a medicare part a claims database analysis. Foot Ankle Int [Internet]. 2015; 36(6):648-55. Available from: https://doi.org/10.1177/1071100715573707

5. Chaudhary SB, Liporace FA, Gandhi A, Donley BG, Pinzur MS, Lin S S, Chaudhry S, Egol KA. Ankle injuries and fractures in the obese patient. Am Orthop Clin North [Internet]. 2011; 42:45-53. Available from: http://dx.doi. org/10.1016/j.ocl.2010.07.003

6. Costigan W, Thordarson DB, Debnath UK. Operative management of ankle fractures in patients with diabetes mellitus. Foot Ankle Int [Internet]. 2007; 28:32-7. Available from: $h$ ttp://dx.doi.org/10.3113/FAl.2007.0006

7. Davidovitch RI, Walsh M, Spitzer A, et al. Functional outcome after operatively treated ankle fractures in the elderly. Foot Ankle Int [Internet]. 2009; 30:728-33. Available from: http://dx.doi.org/10.3113/FAl.2009.0728

8. Donken CC, van Laarhoven CJ, Edwards MJ, Verhofstad MH. Misdiagnosis of OTA type B (Weber B) ankle fractures leading to nonunion.
J Foot Ankle Surg [Internet].2011:50:430-3. Available from: http://dx.doi. org/10.1053/j.jfas.2011.04.031

9. Korim MT, Payne R, Bhatia M. A case-control study of surgical site infection following operative fixation of fractures of the ankle in a large U.K. trauma unit. Bone Jt J [Internet]. 2014; 96-B(5):636-40. Available from: http:// dx.doi.org/10.1302/0301-620X.96B5.33143

10. Lynde MJ, Sautter T, Hamilton GA, Schuberth JM. Complications after open reduction and internal fixation of ankle fractures in the elderly. Foot Ankle Surg [Internet].2012;18(2):103-7. Available from: http://dx.doi.org/10.1016/j. fas.2011.03.010

11. Miller AG, Margules A, Raikin SM. Risk factors for wound complications after ankle fracture surgery. Am J Bone Joint Surg [Internet]. 2012; 94:2047-52 Available from: http://dx.doi.org/10.2106/JBJS.K.01088

12. Nåsell $H$, Ottoson $C$, Törnqvist $H$, Linde J, Ponzer $S$. The impact of smoking on complications after operatively treated ankle fractures - a follow-up study of 906 patients. J Orthop Trauma [Internet]. 2011;25:748-55. Available from: http://dx.doi.org/10.1097/BOT.0b013e318213f217

13. Ovaska M. Complications in ankle fracture surgery. Acta Orthop [Internet]. 2015; 86:1-32. Available from: http://dx.doi.org/10.3109/17453674. 2014.100227

14. Schepers T, Vries MRD, Lieshout EMMV, et al. The timing of ankle fracture surgery and the effect on infectious complications; A case series and systematic review of the literature. Int Orthop [Internet]. 2013; 37:489-94. Available from: http://dx.doi.org/10.1007/s00264-012-1753-9

15. SooHoo NF, Krenek L, Eagan MJ, Gurbani B, Ko CY, Zingmond DS. Complication rates following open reduction and internal fixation of ankle fractures. J Bone Joint Surg Am [Internet].2009;91(5):1042-9. Available from: http://dx.doi:org/10.2106/JBJS.H.00653 